\title{
A Prosopographical Note on IOlbia 71 (Dubois IGDOlbia 11)
}

IOlbia 71 , found in the Olbia excavation in 1938 and first published by A. Beleckij,1) represents a fourth-century BC statue base of Zeus Soter inscribed with the names of priests and members of a thiasos listed in two columns. ${ }^{2)}$ The preserved measurements of the stone are $0.25 \mathrm{~m}$ in height, $0.34 \mathrm{~m}$ in width and $0.22 \mathrm{~m}$ in thickness. Despite serious damage to both ends of the block, the left column (A) allows a reliable restoration, naming seven sons of a certain Leokrates, ordered presumably according to seniority within the family. Unlike Column A, the patronymics of eight other persons listed in the right column (B) are badly damaged and thus either preserve just one or two initial letters or are entirely missing (Fig. 1).

The stone is currently on display in the National Museum of the History of Ukraine in Kiev. Its inspection in the summer of 2006 has prompted some corrections to the previously proposed name restorations in Column B:

Text

Museum Inv. no. 55-237

\begin{tabular}{|c|c|c|}
\hline \multicolumn{3}{|c|}{ 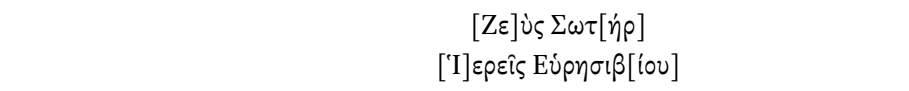 } \\
\hline & {$\left[\Theta_{l}\right] \alpha \sigma i \tau \alpha \iota$} & $\Lambda \varepsilon \omega \varkappa p \alpha \dot{\tau} \eta \varsigma \Pi[[0 \lambda v \chi \alpha \dot{\alpha} p \mu 0 u ?]$ \\
\hline & 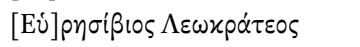 & 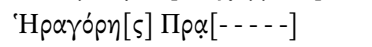 \\
\hline & {$[\Pi 0] \lambda u x p \alpha \dot{\tau} \eta \eta \varsigma \Lambda \varepsilon \omega x p \alpha \dot{\tau} \varepsilon \circ \varsigma$} & 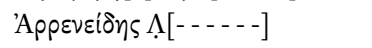 \\
\hline & {$[\Pi 0] \lambda \cup \mu \eta^{\prime} \delta \varsigma \varsigma \Lambda[\varepsilon] \omega x p \alpha ́ \tau \varepsilon[0] \varsigma$} & 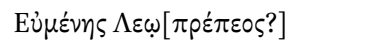 \\
\hline & {$[\Pi \circ \lambda] \cup ́ \sigma \tau \rho \alpha \tau \circ \varsigma \Lambda \varepsilon \omega \varkappa \rho \alpha ́ \tau \varepsilon \circ \varsigma$} & 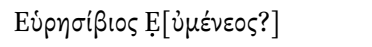 \\
\hline & {$[\Pi \circ \lambda] \cup ́ \chi \alpha \rho \mu \circ \varsigma \Lambda \varepsilon \omega \varkappa \rho \alpha \dot{\tau} \tau \varepsilon \circ \varsigma$} & $\Lambda \varepsilon \omega \pi \rho \varepsilon \dot{\pi} \eta \varsigma$ Eủ $\mu[\varepsilon \dot{v} v \varepsilon \circ \varsigma]$ \\
\hline & {$[\Pi о \lambda \cup ́ \delta] \eta \mu \circ \varsigma \Lambda \varepsilon \omega x \rho \alpha ́ \tau \varepsilon \circ \varsigma$} & 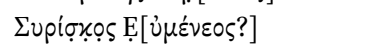 \\
\hline & {$[\Pi 0 \lambda \nu \mu \varepsilon \dot{\varepsilon}] \rho ̣ \omega \nu \Lambda \varepsilon \omega \varkappa \rho \dot{\alpha} \tau \varepsilon[0] \varsigma$} & {$[\Pi \circ] \sigma[\varepsilon \mid \delta \dot{\omega} \omega \nu 10 \varsigma /-\varepsilon \dot{\delta} \delta \iota \pi \pi \varsigma$ ? - } \\
\hline
\end{tabular}

1) Beleckij 1955, 180-91 (with photo) [Bull. ép. 1959, 270; SEG 18.304]. The text was later republished in IOlbia 71 (with photo) and Dubois IGDOlbia 11. Cf. also comments by Jajlenko $(1987,51$, no. 100) and Vinogradov (1981, 64 n. 98; 1989, 147-8).

2) Whereas Beleckij $(1955,181)$ and Knipovič $(1958,165 ; 1966,21)$ date the inscription to the third century BC, an earlier date, in the last third of the fourth century, is more likely. See IOlbia 71; Vinogradov 1989, 136 and n. 4; Dubois IGDOlbia 11. At any rate, according to the lettering, IOlbia 71 should be roughly contemporary with or slightly earlier than the inscription IOSPE I $\mathrm{I}^{2}, 25^{+} 3^{1}$ (= SEG 32.794), which Vinogradov and Karyškovskij (Karyškovskij 1976, 214-5; Vinogradov \& Karyškovskij 1982, 30; Vinogradov 1989, 153-63) place at around 325-320 BC. 


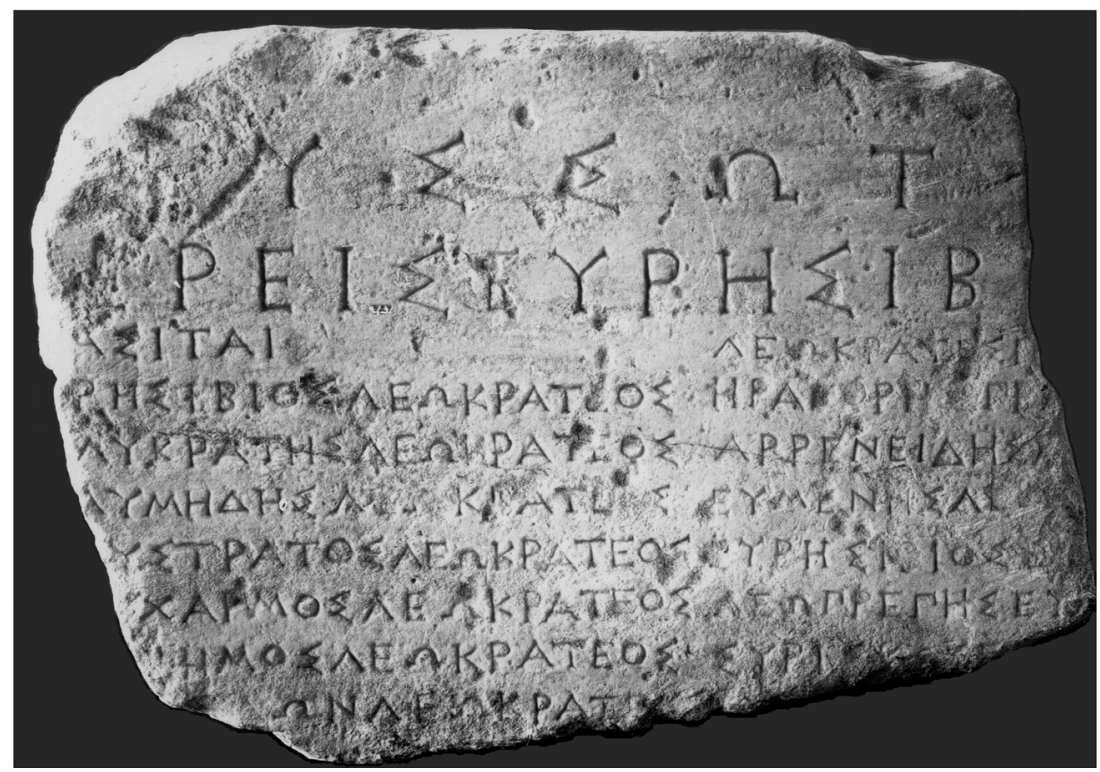

Fig. 1. Inscription IOlbia 71

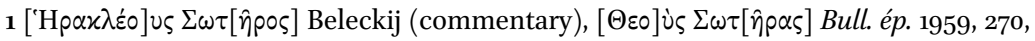

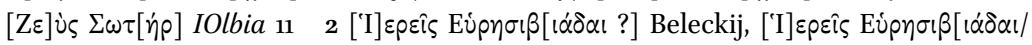
-iov] Dubois

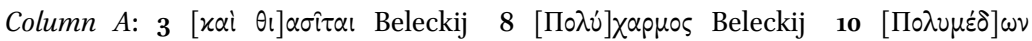
$\Lambda \varepsilon \omega \varkappa \rho \alpha ́ \tau[\varepsilon \circ \varsigma]$ Beleckij

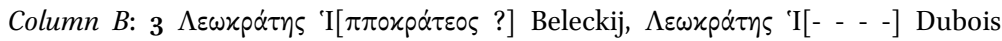

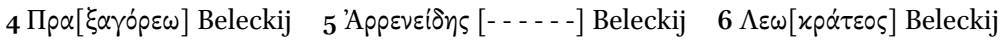

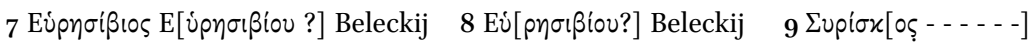

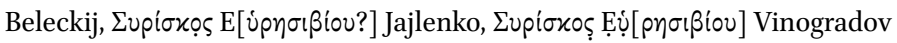

The arrangement of the first two lines with neat and accurately spaced lettering implies that the entire inscription must have had a roughly symmetrical design (see Fig. 2). In the light of this criterion, the traditional restoration, Eip $\sigma / \beta[\llcorner\alpha \delta \alpha l]$, at the end of 1.2 certainly appears too long, making room for an alternative variant,

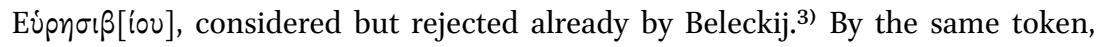
there is no space to restore the conjunction $x \alpha i$ at the beginning of line 3 .

3) On rather vague grounds though. Beleckij 1955, 184: "due to the fact that the existence of priests of Heuresibios is very doubtful"; "(this) option would have been possible under the condition of existence in Olbia of a hitherto unknown local cult of some Heuresibios". 


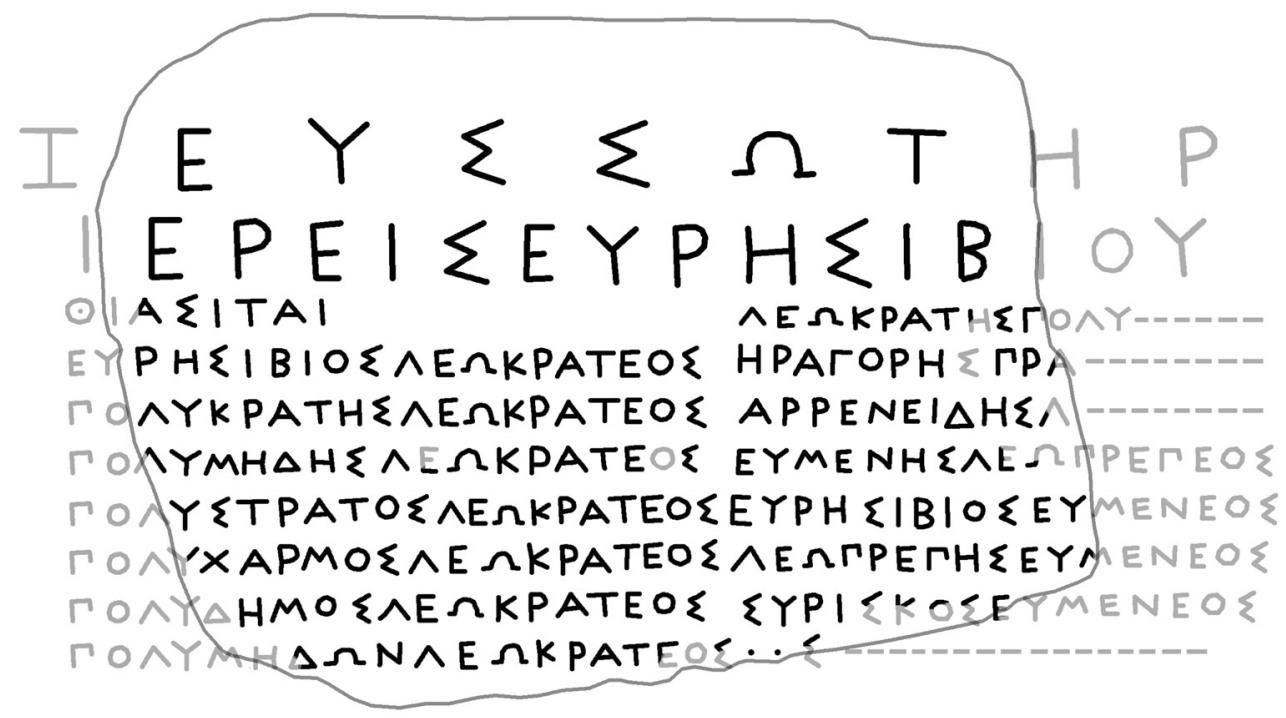

Fig. 2. Inscription IOlbia 71. Drawing by V.F. Stolba

Column B: Seven of the eight names listed in this column read clearly. Their patronymics have been restored, but none of these restorations seems to withstand

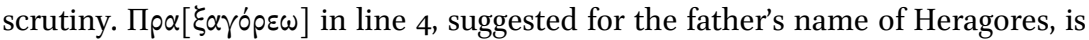
problematic, as it is otherwise unattested in the northern Pontic area. Alternatively, one can point to Prasilas, which occurred in an early fourth-century BC graf-

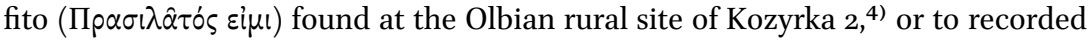
compound names starting with Praxi-.

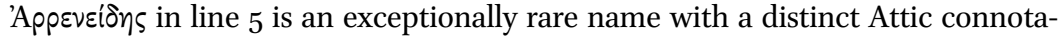
tion. Apart from a single instance from Egypt, ${ }^{5)}$ it seems to be restricted exclusively to Athens, where four different persons of that name are attested in the fifth through the third century BC.6) Given the chronology of the name, its appearance in Olbia does not seem accidental. ${ }^{7)}$ Along with archaeological evidence for trade, the city's

4) Domanskij \& Marčenko 1980, 35-6, fig. 12.a; Tochtas'ev 2000a, 124-5; LGPN IV, p. 289, s.v.

5) In the form 'Appeviôn (SEG 8.573; third/second century BC).

6) LGPN II. Arrheneides, son of Charikles ( $P A$ 2254), whose activity falls between the 350 s and 320s, was a prominent figure in Athens. On Arrheneides and his career, see Davies 1971, 67-8, no. 2254; Wallbank 1983, 198; Hedrick 1989, 135. An Athenian archon of this name (in 262/1 BC; PA 2252; Manni 1975, 24) may be his descendant, as assumed already by Davies $(1971,68)$. The relation of these persons to a certain Arrhe[nei]des, who emerged in 442/1 BC among the epistatai of a statue of Athena $\left(I G \mathrm{I}^{3}, 457.2\right.$; Develin 1989, 89) is uncertain.

7) The physical presence of the Athenians in fourth/third-century BC Olbia is furthermore 
close connections to Athens are documented by a proxeny decree for the Athenians Xanthippos, son of Aristophon, and Philopolis, son of Philopolis, issued in the 340s-330s BC. ${ }^{8)}$ No suggestions for the patronymic of Arrheneides have ever been made, yet the traces of a slanting stroke immediately following the name and possibly belonging to an alpha, a lambda or a my are clearly discernable on the stone.

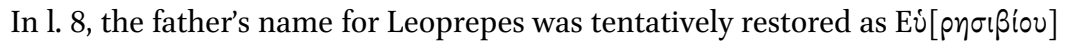
by Beleckij. A clearly discernable oblique stroke which follows an upsilon prompts, however, the reading Eủ $\mu[\varepsilon v \varepsilon \circ \varsigma]$. In view of the Greek practice of naming a child after the grandfather or providing him with at least an element of his grandfather's name, ${ }^{9)}$ Eủ $\mu \varepsilon \dot{\eta} \eta \varsigma \Lambda \varepsilon \omega[-]$ in line 6 is perhaps Leoprepes' father (cf. the left column of the inscription, where the names of six of Leokrates' seven sons begin

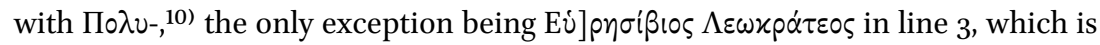
explained by the wish to name the first born after the city's local hero and eponym of this religious association). A similar practice is also evident in connection with

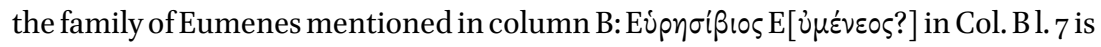
likely to be his first-born son. ${ }^{11)}$ Accordingly, Leoprepes, Eumenes' second son, was the one to acquire his grandfather's name, which leads me to conjecture Eumenes' patronymic as $\Lambda \varepsilon \omega[\pi \rho \varepsilon \dot{\pi} \varepsilon \circ \varsigma$ ?] rather than the earlier proposed $\Lambda \varepsilon \omega[\varkappa \rho \alpha ́ \tau \varepsilon \circ \varsigma]$.

attested by two gravestones of Athenian citizens found in the city: Sosias, son of Kephalos, and Arkephon, son of Kephisodotos (IOSPE I², 232; IOlbia 98). In addition, the Olbian soil yielded two marble statue bases signed by the fourth-century Athenian sculptors Praxiteles and Stratonides (for other works by Attic artists from Olbia, see Farmakovskij 1914, 140-1; Trever 1914, 47-64, pls. 1-3; Waldhauer 1936, 32, no. 270; Vermeule 1977, 813 with n. 4). Notably, Stratonides' statue was commissioned by a certain Leokra[tes], who may possibly be identified with Leokrates P[- - ] (B 1. 3) of our inscription. As argued, however, by W.M. Calder (1971, 326-8; cf. Vinogradov \& Karyškovskij 1976, 26-7), the sculptors themselves apparently did not travel to the northern shore of the Euxine, and both statues should rather be considered imports. See already Levi 1965, 91. Cf., however, Marcadé 1957, 115; Knipovič 1966, 6.

8) Levi 1958, 235-8; Bull. ép. 1960, 278; IOlbia 5; Dubois IGDOlbia 21. Cf. Vinogradov 199o, 51-64 = Vinogradov 1997, 484-92. On Olbia's relationship to Athens, see Karyškovskij 196o, 57-100; Brašinskij 1961, 319-21; 1963, 140-6.

9) On this tradition of name-giving, see Angermann 1893, 17-8; Bechtel \& Fick 1894, xi-xii; Fränkel 1935, 1624; Habicht 1972, 110-3; Stolba 2005, 176 n. 83 .

10) Vinogradov's assertion $(1989,147$ n. 44) that "for the first component in the names of the other six sons philoprogenitive Leokrates used his life motto- $-\pi 0 \lambda v^{\prime \prime}$ is bizarre.

11) Also beyond these families, Heuresibios was an exceptionally popular name in Olbia from the late sixth century $\mathrm{BC}$ through the second century AD. From this city alone, $L G P N$ IV lists 26 persons of this name, whereas it is virtually absent from the other Greek centres of the northern shore of the Black Sea. 
Along with Heuresibios and Leoprepes, Syriskos in line 9 was probably another offspring of Eumenes, despite Vinogradov's attempt to reconstruct his father's

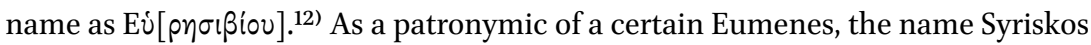
is attested by another inscription (IOSPE $\mathrm{I}^{2}, 201$ II.26), which represents a diachronic list of local Olbian eponyms. ${ }^{13)}$ Given the great rarity of both names in the

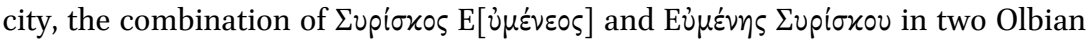
documents is striking, suggesting that they are members of the same family. ${ }^{14)}$

Both the position and lettering of the name Leokrates in line 3 point to its being added to the stone after the whole text had already been engraved, or perhaps at some later point (along with the shape of a lambda, an epsilon, and a kappa, the discrepancy is also evident in the overall height of letters). The first letter of his patronymic is likely to be a $p i$ rather than an iota, which was conjectured by the editor princeps and accepted in subsequent publications of the text. This is apparent from the missing apex on top of the preserved vertical, thus giving grounds to view this Leokrates (II) as a grandson of Leokrates (I) of lines 4-10 of the docu-

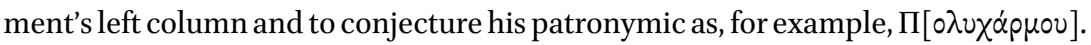
Such restoration would conform to the tentative identification of Leokrates II as a person whose name emerges on the base of Stratonides $(\Lambda \varepsilon \omega x \rho \alpha$ ' $[\eta \varsigma . . .8 \ldots .]$. ov), ${ }^{15)}$ fitting the estimated lacuna size ${ }^{16)}$ as well as the genitive ending -ov preserved on the stone (IOlbia 65).

Heuresibios and Polymedon of IOlbia 71, sons of Leokrates, can be positively identified as persons of the same name listed in IOSPE $\mathrm{I}^{2}, 201 \mathrm{I}$, lines 1 and 39 respectively. ${ }^{17)}$ Leokrates, son of Polymedon, and Eumenes, son of Syriskos, occurring in

12) Vinogradov 1989, 136 n. 4, 148. Cf. also Dubois IGDOlbia, p. 25 (ad no. 11). A yet unpublished Olbian inscription of the early fourth century BC makes mention of a certain Heuresibios, son of Syriskos. See Beleckij 1975, 91; Vinogradov 1989, 135-6. Cf. Dubois IGDOlbia 9;

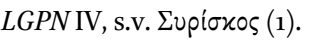

13) Vinogradov 1989, 220.

14) In Olbia, the name Eumenes also seems to be restricted to the members of this family. A homonymous person occurring in an Olbian defixio of the second half of the fourth century

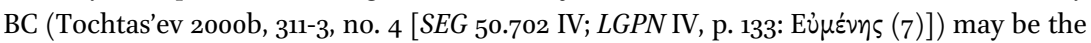
Eumenes of our inscription.

15) See n. 7 .

16) See Calder 1971, 325-6 n. 11, who restores though $\Lambda \varepsilon \omega x \rho \alpha ́[\tau \eta \varsigma ~ E v i p \eta \sigma ı i ́]$ ov. Cf. also Vinogradov $1989,150$.

17) In the second half of the fourth century BC, a certain Polymedon is mentioned in an ostrakon found in the Lower City of Olbia (Lejpunskaja \& Rusjaeva 2006, 112-4; Rusjaeva 2010a, 503-4, no. S-15, pl. 378 = Rusjaeva 2010b, 168, no. 15, pls. 58.2 and 59.2). His relation to the family of Leokrates assumed by Rusjaeva is uncertain, though not impossible, given the date of the graffito scratched on a fragment of an Attic red-figured lekanis of the 
IOSPE $\mathrm{I}^{2}, 201$ I.62 and II. 26, are likely to be descendants of Polymedon and Syriskos of our inscription. The stemmata of these Olbian families are provided in Figure 3.

Testifying to the presence in the city of a cult of a local hero named Heuresibios and of an association of his priests, ${ }^{18)}$ IOlbia 71 offers, unfortunately, no conclusive answer to many other questions which arise in this connection. The text as such provides little clue as to when and by whom this cult and the association were founded. Also about the hero himself we know next to nothing. One might recall an early fourth-century BC graffito purchased in Olbia in 1900 (Tolstoj 1953, no. 44:

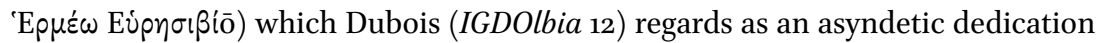
to the god Hermes and the local hero Heuresibios. This is not, however, the only possible interpretation of the inscription. ${ }^{19)}$ Another epigraphic document from Olbia mentions a statue of certain Heuresibios erected by his son, yet here, too, his identity as the homonymous hero cannot be ascertained.

The heroizing of Heuresibios and establishment of his cult account for the striking popularity of his name in Olbia, where, in the fourth century BC through the second century AD, 26 (!) individuals named Heuresibios are attested. ${ }^{20}$ ) This figure is particularly arresting against the background of the complete absence of the name in other Greek cities of the Black Sea region, except for a single instance from Apollonia (fourth century BC).

Attempts to provide a conjectural historical framework for Heuresibios and the emergence of his cult were endeavoured by Vinogradov. ${ }^{21)}$ Following Beleckij's

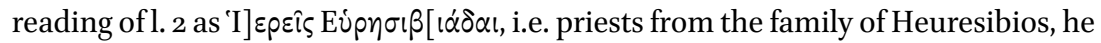
ascended this clan to Heuresibios, son of Syriskos, mentioned in Dubois IGDOlbia 9. According to his restoration and interpretation of an early fourth-century BC

Otchet Group (cf. $A R V^{2}$ 1496-8; Moore 1997, nos. 1095-100) and the rarity of this name in the region.

18) A certain Sosias mentioned by IOSPE $\mathrm{I}^{2}, 3^{2} \mathrm{~B}, 4$ was another such local hero worshipped in the city. The name is very rare in the local onomastics and does not seem to appear on the entire northern shore of the Euxine until the Roman period. Whether this hero is identical to the Athenian Sosias, son of Kephalos $\left(I O S P E \mathrm{I}^{2}, 232\right)$, who died in Olbia in the late fifth or early fourth century BC, remains unknown. On the Greek religious associations in general, see Ziebarth 1896, 33-69; Poland 1909; Nielsen 1950, 111-2; Kloppenborg 1996, 16-30.

19) Heuresibios of this graffito might, for example, be a founder of the cult of Hermes. Cf.

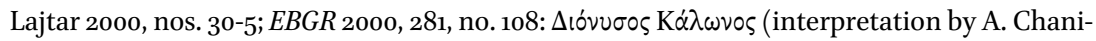
otis). Tolstoj's suggestion that this may be read as a name with a patronymic was rejected by Dubois, who rightly notes that the use of Hermes as a personal name is characteristic of a much later epoch. See Meyersahm 1891, 3-5, 11-3; Masson 1986, 128. Cf. Baumgart 1936, 47; Solin 1971, 108-9.

20) LGPN IV, 135 .

21) Vinogradov 1989. 

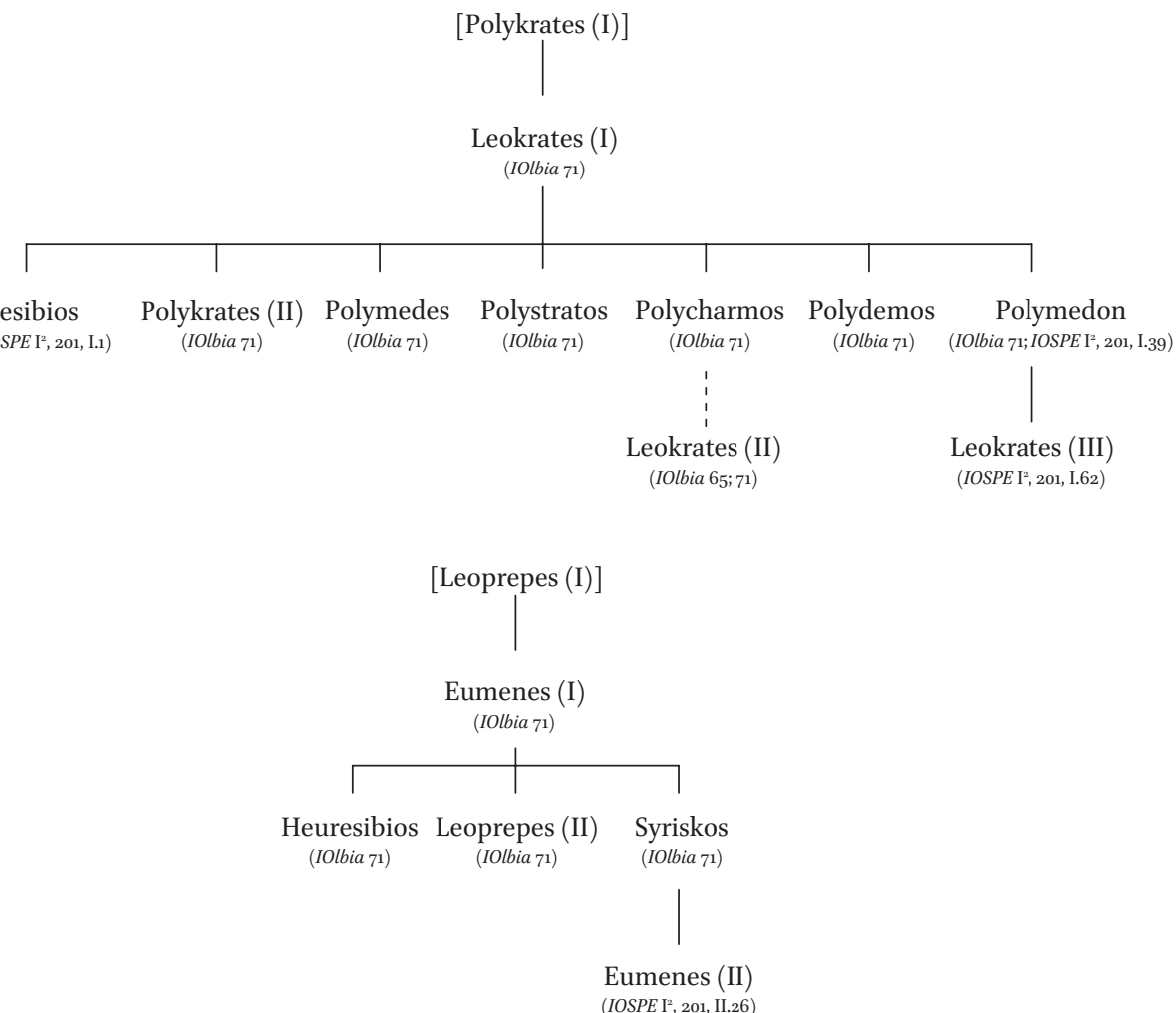

Fig. 3. Stemmata of the Leokrates and Eumenes families

epigram SEG 31.702 (=CEG 2.884), ${ }^{22)}$ this Heuresibios allegedly liberated Olbia from a tyrant - a deed which must have secured him and his kin a prominent position in the city. Although Vinogradov's conjecture of the latter text is far from certain ${ }^{23)}$ his hypothesis about the Olbian tyranny cannot be dismissed so easily, as it is independently supported by the local numismatic testimony. ${ }^{24)}$

Little specific can be deduced about the priesthood associated with the cult of this hero, apart from it appearing to have been the exclusive preserve of a corporate descent-group. As we could see, the majority of priests listed in IOlbia 71 are close relatives from at least two families, probably kin: those of Leokrates and Leoprepes. A shared component, $\Lambda \varepsilon \omega$-, of the names of these two persons

\footnotetext{
22) Vinogradov 1981; 1989, 142.

23) Lebedev 1996, 263-8.

24) Vinogradov 1981, 53-6; Stolba 2009, 29.
} 
suggests that they might in fact be brothers, though this may also be purely accidental. Leokrates, if not a founder, must have also been closely related to the cult of Heuresibios, just like his sons, judging by the name of his first-born. His absence from the list of priests and thiasitai probably indicates that by the time of the dedication he was no longer alive. The argument might be stretched a little further to conclude that the priests whose names occur on the stone and who organised themselves in a thiasos ${ }^{25)}$ may not have been priests $\delta ı \dot{\alpha} \beta$ íov, i.e. for life. Priesthood as such rarely required a full-time dedication and might sometimes have allowed a combination of liturgical authority and some civic duties. ${ }^{26)}$ It is therefore unlikely that all fifteen persons listed in IOlbia 71 were priests simultaneously, although

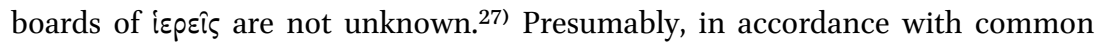
Greek practice, they performed their duties individually, which is also suggested by the presence of an addendum in 1.3 . The above prosopographical observations suggest their chronological listing, yet one cannot tell whether these priests were appointed annually or for a longer period, as the rules for such appointments varied across time and place.

University of Aarhus

Vladimir F. Stolba

Department of Anthropology, Archaeology and Linguistics

Viktor Albecks Vej 2, build. 1414, 8000 Aarhus C, Denmark

klavs@hum.au.dk

Received: February 2011; accepted: June 2011

\section{Bibliography}

Angermann, C. 1893. Beiträge zur griechischen Onomatologie, Jahresbericht der Fürsten- und Landesschule St. Afra in Meissen vom Juli 1892 bis Juli 1893 (Meissen), 1-25

Avram, A., Marcu, M. 1999. Monument epigrafic inedit de la Histria, SCIVA 50, 71-7

Baumgart, J. 1936. Die römischen Sklavennamen (Breslau)

25) Less likely is the possibility that this association embraced a larger body of Heuresibios' worshippers, as then it becomes unclear why, out of the whole thiasos, only priests participated in the dedication of a statue to Zeus Soter. On the associations of priests, cf.

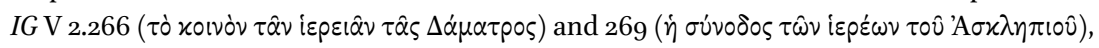
Mantineia.

26) Cf., e.g., Stengel 1890, 26.

27) Three priests of Dionysos Karpophoros are mentioned, for example, in an early secondcentury AD inscription from Histria (Avram \& Marcu 1999, 71-7). 
Bechtel, F., Fick, A. 1894. Die griechischen Personennamen nach ihrer Bildung erklärt und systematisch geordnet (Göttingen)

Beleckij, A.A. 1955. Grečeskaja nadpis' na baze statui iz Ol'vii, VDI 2, 180-91

- 1975. Tri epigrafičeskich pamjatnika, in: Novejšie otkrytija sovetskich archeologov. Tezisy dokladov konferencii, 2 (Kiev), 91

Brašinskij, I.B. 1961. Ol'vija i Afinyv IVv. do n.e., ZOAO 1, 319-21

— 1963. Afiny i Severnoe Pričernomor'e v VI-II vv. do n.e. (Moskva)

Calder, W.M. 1971. Stratonides Athenaios, AJA 75, 325-9

Davies, J.K. 1971. Athenian Propertied Families (Oxford)

Develin, R. 1989. Athenian Officials 684-321 BC (Cambridge)

Domanskij, Ja.V., Marčenko, K.K. 1980. Poselenie ol'vijskoj chory Kozyrka 2, ASborGE 21, 20-38

Farmakovskij, B.V. 1914. Pamjatniki antičnoj kul'tury, najdennye v Rossii, IAK 51, 140-4

Fränkel, E. 1935. Namenwesen, RE 16, 1611-70

Habicht, Ch. 1972. Beiträge zur Prosopographie der altgriechischen Welt, Chiron 2, 103-34

Hedrick, S.W., Jr. 1989. The Phratry from Paiania, ClQ 39, 126-35

Jajlenko, V.P. 1987. Materialy k 'Korpusu lapidarnych nadpisej Ol'vii', in: Pavlovskaja, A.I. (ed.) Issledovanija po epigrafike i jazykam drevnej Anatolii, Kipra i antičnogo Severnogo Pričernomor'ja (Moskva), 4-105

Karyškovskij, P.O. 196o. Ol'vija i Afinskij sojuz, MASP 3, 57-100 1976. Iz istorii Ol'vii v ranneellinističeskoe vremja ( $k$ IOSPE I2, 25), MASP 8, 212-5

Kloppenborg, J.S. 1996. Collegia and thiasoi: Issues in Function, Taxonomy and Membership, in: Kloppenborg, J.S., Wilson, S.G. (eds.) Voluntary Associations in the Graeco-Roman World (London), 16-30

Knipovič, T.N. 1958. Epigrafičeskie nachodki iz raskopok Ol'vii 1920-1954 gg., SovA 28, 162-77 1966. Grečeskoe lapidarnoe pis'mo v pamjatnikach Ol'vii, NumEpigr 6, 3-30

Lajtar, A. 200o. Die Inschriften von Byzantion, I: Die Inschriften (Bonn)

Lebedev, A. 1996. A New Epigram for Harmodios and Aristogeiton, ZPE 112, 263-8

Lejpunskaja, N.A., Rusjaeva, A.S. 2006. Častnyj musejon v Ol'vii Pontijskoj, Bosporskie issledovanija $11,108-26$

Levi, E.I. 1958. Kistorii torgovli Ol'vii VIV-III vv. do n.e. (Po epigrafičeskim pamjatnikam agory), SovA $28,234-47$ 1965. Ol'vijskaja nadpis's posvjaščeniem Apollonu Vraču, VDI 2, 86-95

Manni, E. 1975. Arconti eponimi ateniesi 292/1-141/o A.C., Historia 24, 17-32

Marcadé, J. 1957. Recueil des signatures de sculpteurs grecs, II (Paris)

Masson, O. 1986. Pape-Benzeleriana IX-Madame Artemis, ZPE 66, 126-30

Meyersahm, H. 1891. Deorum nomina hominibus imposita (Kiel)

Moore, M.B. 1997. Attic Red-Figured and White-Ground Pottery (Princeton)

Nielsen, M. 1950. Geschichte der griechischen Religion, 2 (München)

Poland, F. 1909. Geschichte des griechischen Vereinswesen (Leipzig)

Rusjaeva, A.S. 2010a. Graffiti, in: Lejpunskaja, N.A. et al. (eds.) The Lower City of Olbia (Sector $N G S$ ) in the 6th century BC to the 4th century $A D$ (Aarhus), 499-517

2o1ob. Graffiti Ol'vii Pontijskoj (Simferopol) 
Solin, H. 1971. Beiträge zur Kenntnis der griechischen Personennamen in Rom, I (Helsinki)

Stengel, P. 189o. Die griechischen Kultusaltertümer (München)

Stolba, V.F. 2005. Hellenistic Chersonesos: Towards Establishing a Local Chronology, in: Stolba, V.F., Hannestad, L. (eds.) Chronologies of the Black Sea Region in the Period c. 400-100 BC (Aarhus), 153-77

Stolba, V.F. 2009. The Fifth-Century BC Tyrannic Issues of the Northern Black Sea Coast: Local Phenomenon or Achaemenid Influence?, in: XIV International Numismatic Congress, Glasgow 2009. Abstracts of Papers (Glasgow), 29

Tochtas'ev, S.R. 20ooa. Iz onomastiki Severnogo Pričernomor'ja: X-XVII, Hyperboreus 6, $124-56$

20oob. Novye tabellae defixionum iz Ol'vii, Hyperboreus 6, 296-316

Tolstoj, I.I. 1953. Grečeskie graffiti drevnich gorodov Severnogo Pričernomorjja (Moskva/ Leningrad)

Trever, K. 1914. Mramornye skul'ptury iz Ol'vii, IAK 54, 47-64

Vermeule, C.C. 1977. Greek and Roman Sculpture from the Northern Coast of the Black Sea, Burlington Magazine 119, 810-8

Vinogradov, Ju.G. 1981. Sinopa i Ol'vija v Vv. do n.e. Problema političeskogo ustrojstva, II, VDI 3, 49-75

1989. Političeskaja istorija Ol'vijskogo polisa VII-I vv. do n.e.: Istoriko-epigrafičeskoe issledovanie (Moskva)

— 1990. Olviopolityv Severo-Zapadnoj Tavrike, in: Vinogradov, Ju.G., et al. (eds.) Drevnee Pričernomorje. Materialy I Vsesojuznych čtenij pamjati professora Petra Osipoviča Karyškovskogo (Odessa), 51-64

1997. Pontische Studien (Mainz)

Vinogradov, Ju.G., Karyškovskij, P.O. 1976. Ol'vijskij dekret Kanoba o den'gach i stoimost' dragocennych metalov na Ponte $v I V v$. do n.e., VDI 4, 20-42

— 1982. Kallinik, syn Evksena. Problemy političeskoj i social'no-ekonomičeskoj istorii Ol'vii vtoroj poloviny $I V v$. do n.e. I, VDI 4, 26-46

Waldhauer, O. 1936. Die antiken Skulpturen der Ermitage, III (Berlin/Leipzig)

Wallbank, M.B. 1983. Leases of Sacred Properties in Attica, II, Hesperia 52, 177-99

Ziebarth, E. 1896. Das griechische Vereinswesen (Leipzig)

\section{Abbreviations}

ASborGE Archeologičeskij sbornik Gosudarstvennogo Ermitaža. Leningrad/St Petersburg EBGR Epigraphic Bulletin for Greek Religion, Kernos

IAK Izvestija imperatorskoj Archeologičeskoj Komissii. St Petersburg

MASP Materialy po archeologii Severnogo Pričernomor'ja. Odessa

RosA Rossijskaja archeologija. Moskva

SCIVA Studii şi Cercetari de Istorie Veche şi Arheologie. Bucharest

ZOAO Zapiski Odesskogo archeologičeskogo obščestva. Odessa 